\title{
Catalytic Ozonation of Oxalate with a Cerium Supported Palladium Oxide: An Efficient Degradation Not Relying on Hydroxyl Radical Oxidation
}

\author{
Tao Zhang, ${ }^{\dagger}$ Weiwei Li, ${ }^{\ddagger}$ and Jean-Philippe Croué, ${ }^{*,+}$ \\ ${ }^{\dagger}$ Water Desalination and Reuse Center (WDRC), King Abdullah University of Science and Technology (KAUST), Thuwal 4700, \\ Kingdom of Saudi Arabia \\ ${ }^{\ddagger}$ Research Center for Eco-Environmental Sciences (RCEES), Chinese Academy of Sciences, Beijing 100085, China
}

Supporting Information

ABSTRACT: The cerium supported palladium oxide (PdO/ $\mathrm{CeO}_{2}$ ) at a low palladium loading was found very effective in catalytic ozonation of oxalate, a probe compound that is difficult to be efficiently degraded in water with hydroxyl radical oxidation and one of the major byproducts in ozonation of organic matter. The oxalate was degraded into $\mathrm{CO}_{2}$ during the catalytic ozonation. The

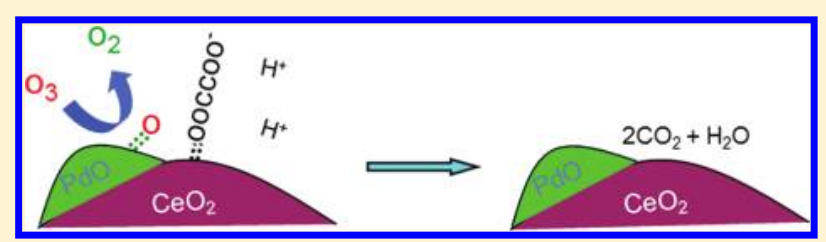
molar ratio of oxalate degraded to ozone consumption increased with increasing catalyst dose and decreasing ozone dosage and $\mathrm{pH}$ under the conditions of this study. The maximum molar ratio reached around 1, meaning that the catalyst was highly active and selective for oxalate degradation in water. The catalytic ozonation, which showed relatively stable activity, does not promote hydroxyl radical generation from ozone. Analysis with ATR-FTIR and in situ Raman spectroscopy revealed that 1) oxalate was adsorbed on $\mathrm{CeO}_{2}$ of the catalyst forming surface complexes, and 2) $\mathrm{O}_{3}$ was adsorbed on PdO of the catalyst and further decomposed to surface atomic oxygen $\left({ }^{*} \mathrm{O}\right)$, surface peroxide $\left({ }^{*} \mathrm{O}_{2}\right)$, and $\mathrm{O}_{2}$ gas in sequence. The results indicate that the high activity of the catalyst is related to the synergetic function of $\mathrm{PdO}$ and $\mathrm{CeO}_{2}$ in that the surface atomic oxygen readily reacts with the surface cerium-oxalate complex. This kind of catalytic ozonation would be potentially effective for the degradation of polar refractory organic pollutants and hydrophilic natural organic matter.

\section{INTRODUCTION}

Catalytic ozonation with metal oxides is a potential process to enhance the degradation of recalcitrant organics in water. It is generally accepted that catalytic ozonation with metal oxides can be ascribed to either of the two pathways: ozone decomposition on the catalyst surface generating hydroxyl radicals and direct ozone oxidation of surface metal-organic complexes. ${ }^{1}$ In the past decade, many studies were conducted on catalytic ozonation that follows the hydroxyl radical pathway. Successful works were accomplished on the preparation of efficient catalyst accelerating hydroxyl radical production from ozone and the identification of active sites involved in this process. ${ }^{2-4}$ With regard to catalytic ozonation relying on surface complexes, a lot of publications refer to the degradation of organic acids with mono- or hybrid- metal oxides as catalysts. ${ }^{5-7}$ However, minor achievements were made in this domain of research because of the lack of highly efficient catalysts as well as the difficulties in identifying active sites and active oxidant species, information that is essential to understand the mechanism and optimize the catalyst preparation. ${ }^{1}$

Hydroxyl radical has high reaction rate constants with almost all organics in water. However, hydroxyl radical oxidation is not effective to degrade aliphatic hydrophilic compounds that contain carbonyl or carboxylic groups, e.g., the products formed during the ozonation of natural organic matter. ${ }^{8}$ This is because the consumption of hydroxyl radical by bicarbonates/carbonates $\left(k=8.5 \times 10^{6} / 3.9 \times 10^{8} \mathrm{M}^{-1} \mathrm{~s}^{-1}\right)$ and ozone $\left(k=1 \times 10^{8}-2 \times\right.$ $\left.10^{9} \mathrm{M}^{-1} \mathrm{~s}^{-1}\right)$ are usually faster than its reactions with the saturated compounds. ${ }^{8}$ From this point, catalytic ozonation through a complexation pathway would be more selective and efficient for the degradation of saturated hydrophilic organics, if highly active catalyst can be prepared.

Oxalate is one of the major byproducts in ozonation or advanced oxidation of natural organic matter and organic pollutants. ${ }^{9}$ Its degradation in reaction with both molecular ozone $\left(k \leq 0.04 \mathrm{M}^{-1} \mathrm{~s}^{-1}\right)$ and hydroxyl radical $(k=7.7 \times$ $\left.10^{6} \mathrm{M}^{-1} \mathrm{~s}^{-1}\right)$ are relatively low. ${ }^{10}$ Therefore, it is usually used as a probe compound to study catalytic ozonation that follows surface complexation pathway. $\mathrm{MnO}_{2}, \mathrm{Fe}_{2} \mathrm{O}_{3}, \mathrm{Co}_{3} \mathrm{O}_{4}$, and $\mathrm{NiO}$ had been found effective in the catalytic ozonation of oxalic acid but the removal rates at normal $\mathrm{pHs}$ in a reasonable reaction time were too low and the ozone doses were too high for practical uses. $5,7,11,12$ There are still no data on ozone consumption for oxalate degradation which is critical to evaluate the catalysis efficiency. No evidence shows active sites and active oxidant species that are responsible for oxalate degradation, the information

Received: June 28, 2011

Accepted: October 4, 2011

Revised: October 1, 2011

Published: October 04, 2011 
that is needed to better understand the reaction pathway and tailor cost-effective catalysts.

PdO supported on ceria-zirconium oxide has been used successfully as a three-way catalyst for automobile-exhausted gases to reduce $\mathrm{NO}$ and oxidize $\mathrm{CO}$ and hydrocarbons. ${ }^{13}$ With regard to catalytic ozonation of organic compounds in water with supported $\mathrm{PdO}$, there is still no report. $\mathrm{PdO}$ had been found effective in decomposing aqueous ozone, ${ }^{14}$ but intermediates in this process are unknown. $\mathrm{CeO}_{2}$ can reduce bromate formation during ozonation, while it is inactive in promoting ozone decomposition and organic compound degradation. ${ }^{15}$ In this study, the effectiveness and efficiency of a cerium supported palladium oxide $\left(\mathrm{PdO} / \mathrm{CeO}_{2}\right)$ in catalytic ozonation was tested using oxalate as a probe compound. In order to elucidate the efficient pathway for catalytic ozonation not relying on hydroxyl radical, surface active sites of the catalyst and surface oxygen intermediates formed from ozone decomposition were investigated with ATR-FTIR and in situ Raman spectroscopy.

\section{EXPERIMENTAL SECTION}

Metal Oxides Preparation. The support $\mathrm{CeO}_{2}$ was synthesized with a urea-hydrothermal method. $\mathrm{Ce}\left(\mathrm{NO}_{3}\right)_{3} \cdot 6 \mathrm{H}_{2} \mathrm{O}$ and urea were dissolved in distilled water with a molar ratio of $1: 3$. The mixture was heated at $140^{\circ} \mathrm{C}$ for $5 \mathrm{~h}$. After filtration and repeated washing, the precipitate was dried at $120^{\circ} \mathrm{C}$ for $2 \mathrm{~h}$ and calcined at $450{ }^{\circ} \mathrm{C}$ for $4 \mathrm{~h}$. $\mathrm{PdO} / \mathrm{CeO}_{2}$ was prepared by impregnating the $\mathrm{CeO}_{2}$ with $\mathrm{Pd}\left(\mathrm{NO}_{3}\right)_{2}$ aqueous solution with incipient wetness. The impregnated oxide was dried at $60{ }^{\circ} \mathrm{C}$ and finally calcined in air at $550{ }^{\circ} \mathrm{C}$ for $2 \mathrm{~h}$. Palladium mass proportion of the $\mathrm{PdO} / \mathrm{CeO}_{2}$ was measured to be $3.8 \%$. PdO particle was prepared by direct calcination of the dried $\mathrm{Pd}\left(\mathrm{NO}_{3}\right)_{2}$ at $550{ }^{\circ} \mathrm{C}$ for $2 \mathrm{~h}$.

Characterization. BET surface area of the metal oxides was determined on a Micromeritics ASAP2000 analyzer. $\mathrm{pH}_{\mathrm{pzc}}(\mathrm{pH}$ at which the surface is zero-charged) was determined with acid-base titration. Average particle size was measured on a Mastersizer 2000 laser particle size analyzer. STEM (scanning transmission electron microscopy) pictures taken on a Titan 80-300 transmission electronic microscope were used to characterize the dispersion of $\mathrm{PdO}$ on $\mathrm{CeO}_{2}$. The major characteristics of the metal oxides used in this study are listed in Table S1 (Supporting Information).

Experimental Procedure. Batch Reaction. Milli-Q water at room temperature $\left(21^{\circ} \mathrm{C}\right)$ was continuously bubbled with gaseous ozone produced with an ozone generator (3S-A5, Tonglin Technology) from dried oxygen gas. The aqueous ozone concentration was analyzed continuously with an ultraviolet spectrometer (Hach 500) at $258 \mathrm{~nm}$ (molar absorbance coefficient $=$ $3000 \mathrm{M}^{-1} \mathrm{~cm}^{-1}$ ) until it reached a steady state. The steady ozone concentration in water was controlled by adjusting the electric current of the ozone generator. Predetermined volume of ozone stock solution was quickly mixed with tetraborate buffered oxalate solution in a glass reactor. In the case of catalytic ozonation, the catalyst (mostly at a dose of $150 \mathrm{mg} \mathrm{L}^{-1}$ unless specified) was also instantly introduced into the reaction solution. Then, the reactor was sealed and magnetically stirred. Samples were taken at each time-point and then filtered through $0.45 \mu \mathrm{m}$ acetate-fiber syringe filters and purged with pure $\mathrm{N}_{2}$ to remove residual ozone in water. The filtration had no impact on the oxalate concentration. In order to reduce the impact of filtration on aqueous ozone, $50 \mathrm{~mL}$ of the ozone stock solution was pressed through the filter before sample filtration for ozone analysis. Then, the filtration had nearly no impact on the aqueous ozone concentration when the filter had been pretreated in this way.

Semicontinuous Reaction. Gaseous ozone (concentration = $21 \mathrm{mg} \mathrm{O}_{3} \mathrm{~L}^{-1}$, flow rate $=3.0 \mathrm{~L} \mathrm{~min}^{-1}$ ) was continuously introduced into a $500 \mathrm{~mL}$ reaction solution $(0.2 \mathrm{mM}$ oxalate in $10 \mathrm{mM}$ tetra-borate buffer) in a glass vessel. After the first $10 \mathrm{~min}$, $10 \mathrm{~mL}$ of reaction solution was withdrawn from the reaction vessel with a syringe. Subsequently, the same volume of oxalate stock solution (10 mM, buffered with $10 \mathrm{mM}$ tetraborate) was immediately added into the reactor. The same operation was repeated 30 times. The samples were filtered with $0.45 \mu \mathrm{m}$ acetate fiber filters and then purged with pure $\mathrm{N}_{2}$ to remove residual ozone.

Analysis. Ozone concentration in reaction solution was directly determined on the UV spectrometer at $258 \mathrm{~nm}$ after the filtration, using the tetraborate buffer $(10 \mathrm{mM}$ and $\mathrm{pH} 6.5)$ as zero background, because oxalate had no detectable absorbance at this wavelength. Oxalate was analyzed on a Dionex ICS-1600 IC equipped with an AS-9 column. The mobile phase was $9 \mathrm{mM}$ $\mathrm{Na}_{2} \mathrm{CO}_{3}$ at a flow rate of $1.0 \mathrm{~mL} \mathrm{~min}^{-1}$. TOC was measured on a Teledyne Tekmar TOC Fusion analyzer. Atrazine used as a probe compound of hydroxyl radical in this study was determined on a Waters HPLC equipped with a Symmetry C-18 column at a UV wavelength of $220 \mathrm{~nm}$. The mobile phase was isocratic $\mathrm{H}_{2} \mathrm{O}$ /acetonitrile at a volume ratio of $3 / 7$ and a flow rate of $1.0 \mathrm{~mL} \mathrm{~min}^{-1}$.

Dissolved palladium and cerium ions were determined on an ICP-MS (Agilent 7500) with detection limits of $9.4 \times 10^{-4}$ and $1.7 \times 10^{-2} \mu \mathrm{g} \mathrm{L}^{-1}$ for the two cations, respectively. Palladium content of the catalyst was also determined by the ICP-MS after digestion of the catalyst with $\mathrm{HCl}+\mathrm{HNO}_{3}(\mathrm{v} / \mathrm{v}=3: 1)$ and $\mathrm{HF}$ in sequence.

A Perkin Elmer FTIR spectrometer (Spectrum 100) equipped with a Universal ATR accessory was used to characterize the catalyst surface in presence or absence of ozone and oxalate. In the study of aqueous ozone adsorption, the suspension of metal oxide $\left(750 \mathrm{mg} \mathrm{L}^{-1}\right)$ was continuously bubbled with gaseous ozone (concentration $=21 \mathrm{mg} \mathrm{L}^{-1}$, flow rate $=3.0 \mathrm{~L} \mathrm{~min}^{-1}$ ) for over $10 \mathrm{~min}$ in a $25 \mathrm{~mL}$ glass tube which was cooled with ice. The suspension was quickly dropped on the $\mathrm{ZnSe}$ crystal of the ATR accessory with a glass pipet, covered with a stainless lid, and scanned in the range of $800-4000 \mathrm{~cm}^{-1}$ at a resolution of $4 \mathrm{~cm}^{-1}$. In the study of oxalate adsorption, $0.2 \mathrm{mM}$ oxalate in $10 \mathrm{mM}$ tetraborate buffer of $\mathrm{pH} 6.5$ was mixed with metal oxide particles $\left(150 \mathrm{mg} \mathrm{L}^{-1}\right)$ and stirred for over $2 \mathrm{~h}$. After settling, the particles were dropped on the ATR crystal and analyzed at the same conditions as that described above.

In situ Raman spectra were taken on a confocal microscopic Raman spectrometer (Aramis, Horiba Jobin Yvon) with a $9 \mathrm{~mW}$ $633 \mathrm{~nm}$ laser light irradiation. Before analysis, the metal oxides were pressed into slices of $1-2 \mathrm{~mm}$ in thickness and $13 \mathrm{~mm}$ in diameter. The slice was then stuck on a microscope slide with a double-sided tape, wetted with Milli-Q water, and then blown with gaseous ozone (concentration $=1.5 \mathrm{mg} \mathrm{L}^{-1}$, flow rate $=1.4$ $\mathrm{L} \mathrm{min}^{-1}$ ) which was humidified through a gas washer. The slice was scanned from 300 to $1200 \mathrm{~cm}^{-1}$ at a resolution of $1 \mathrm{~cm}^{-1}$ and a duration time of $100 \mathrm{~s}$ under the humidified ozone gas.

\section{RESULTS AND DISCUSSION}

Effectiveness. Figure 1A shows the decrease in oxalate concentration in batch reaction mode during catalytic ozonation 


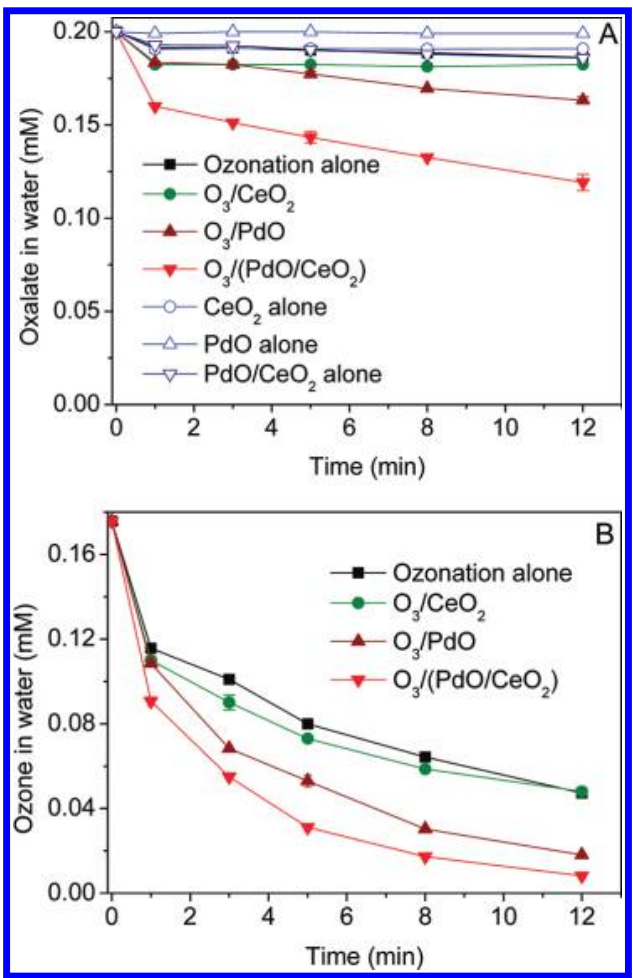

Figure 1. Oxalate removal in catalytic ozonation and adsorption alone with the single and the binary oxides (A) and ozone decomposition in the catalytic ozonation (B). Experimental conditions: ozone dose $=$ $0.18 \mathrm{mM}$, initial oxalate concentration $=0.2 \mathrm{mM}$, oxide dose $=150 \mathrm{mg} \mathrm{L}^{-1}$, $\mathrm{T}=21{ }^{\circ} \mathrm{C}, 10 \mathrm{mM}$ tetraborate buffered $\mathrm{pH}=6.5$.

and adsorption alone with $\mathrm{CeO}_{2}, \mathrm{PdO}$, and $\mathrm{PdO} / \mathrm{CeO}_{2}$. Oxalate was quite stable during ozonation alone (absence of catalyst). Its concentration decreased less than $0.014 \mathrm{mM}$ in $12 \mathrm{~min}$ at the ozone dose of $0.18 \mathrm{mM}$. Oxalate loss in $\mathrm{O}_{3} / \mathrm{CeO}_{2}$ approximated the sum of that removed during ozonation alone and that in $\mathrm{CeO}_{2}$ adsorption alone, meaning that $\mathrm{CeO}_{2}$ has no activity in oxalate degradation. PdO showed nearly no adsorption for oxalate. However, it promoted oxalate removal during catalytic ozonation to $0.037 \mathrm{mM}$. Even $\mathrm{PdO}$ mass on the $\mathrm{PdO} / \mathrm{CeO}_{2}$ was less than $4 \%$, the binary oxide showed a much higher efficiency than PdO. Oxalate loss reached to $0.08 \mathrm{mM}$ in $\mathrm{O}_{3} /\left(\mathrm{PdO} / \mathrm{CeO}_{2}\right)$, which can largely be attributed to degradation because the oxalate loss in $\mathrm{PdO} / \mathrm{CeO}_{2}$ adsorption alone was only $0.014 \mathrm{mM}$.

After catalytic ozonation with $\mathrm{PdO} / \mathrm{CeO}_{2}$, the presence of cerium and palladium ions in the reaction solution were examined. The cerium ion concentration was below the detection limit. The concentration of palladium ion was $0.24 \mu \mathrm{g} \mathrm{L}^{-1}$, which was $4.2 \times 10^{-5}$ times the one of the solid PdO dose. The suspension was filtered with a $0.45 \mu \mathrm{m}$ filter and ozonated again without the presence of $\mathrm{PdO} / \mathrm{CeO}_{2}$. No further oxalate degradation was observed (not shown). Therefore, the oxalate degradation is due to heterogeneous catalysis but not due to catalysis effect of trace palladium ion in water. It was reported that effective catalytic oxalate degradation with several typical metal oxides were achieved only at much lower pHs (e.g., 4.1 and 3.2 for $\mathrm{MnO}_{2}, 2.5$ for $\mathrm{Fe}_{2} \mathrm{O}_{3}$ and $\mathrm{Co}_{2} \mathrm{O}_{3}$, and 2.4 for $\mathrm{NiO}$ ) and continuous ozone introduction during the reaction over 30 min. ${ }^{5,7,11,12}$ This binary oxide seems to be more efficient for practical catalytic ozonation reaction.

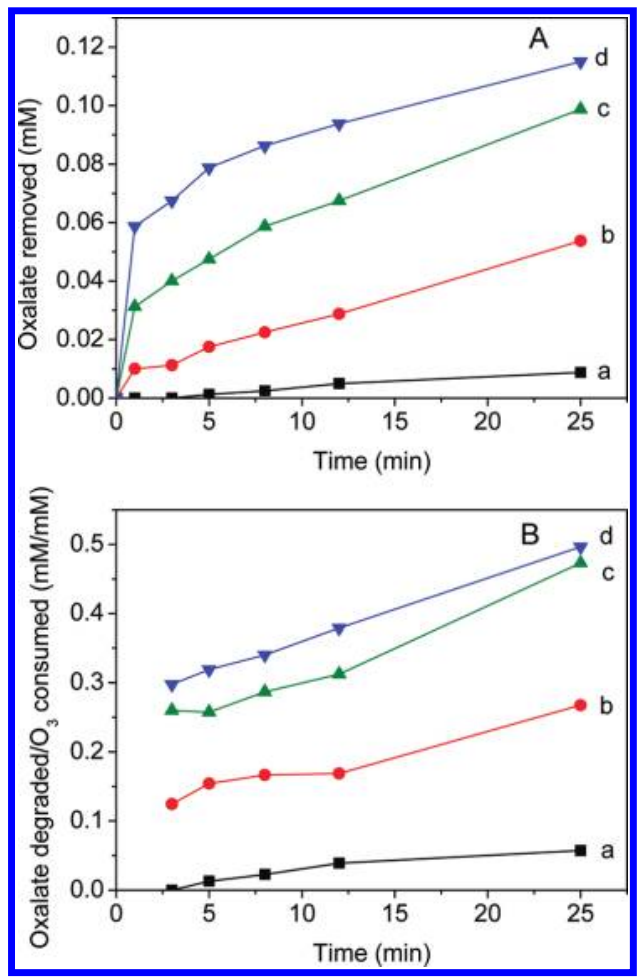

Figure 2. Effect of catalyst dose $\left(\mathrm{a}-0 \mathrm{mg} \mathrm{L}^{-1}, \mathrm{~b}-70 \mathrm{mg} \mathrm{L}^{-1}, \mathrm{c}-150 \mathrm{mg} \mathrm{L}^{-1}\right.$, and $\mathrm{d}-250 \mathrm{mg} \mathrm{L}^{-1}$ ) on oxalate removal (A) and the effective ozone consumption ratio (B) in the catalytic ozonation. Experimental conditions: ozone dose $=0.18 \mathrm{mM}$, initial oxalate concentration $=0.2 \mathrm{mM}, T=21^{\circ} \mathrm{C}$, $10 \mathrm{mM}$ tetraborate buffered $\mathrm{pH}=6.5$.

The ozone decay recorded during ozonation in the presence or in the absence of the oxides exhibited a similar pattern as the oxalate removal profile (Figure 1B). Consistent with previous results, ${ }^{15} \mathrm{CeO}_{2}$ nearly did not improve ozone decomposition. The ozone depletion in water was promoted by $\mathrm{PdO}$ and to a higher rate by $\mathrm{PdO} / \mathrm{CeO}_{2}$.

$\mathrm{PdO}$ seems to be an active metal oxide in oxalate degradation and ozone decomposition. The activity was significantly improved by $\mathrm{CeO}_{2}$ support. The disperse effect of $\mathrm{CeO}_{2}$ for small $\mathrm{PdO}$ crystals on the surface (i.e., the effect against $\mathrm{PdO}$ particle agglomeration) (Figure S1, Supporting Information) as well as the adsorption of oxalate on $\mathrm{CeO}_{2}$ possibly contributed to the high activity of the $\mathrm{PdO} / \mathrm{CeO}_{2}$.

Effect of Catalyst Dose. The increase of $\mathrm{PdO} / \mathrm{CeO}_{2}$ dose from 0 to $250 \mathrm{mg} \mathrm{L}^{-1}$ significantly accelerated oxalate removal (Figure 2) as well as ozone decomposition (Figure S2A, Supporting Information). The oxalate removal in the presence of ozone (i.e., catalytic ozonation) was much more significant than that in the absence of ozone (i.e., adsorption alone) (Figure S2B, Supporting Information). Moreover, ozonation did not improve the absorbability of the catalyst for oxalate (Figure S2B, Supporting Information). Therefore, the high oxalate removal in the catalytic ozonation was due to degradation but not adsorption. It is interesting that a further loss of oxalate concentration by $0.02 \mathrm{mM}$ was observed during the catalytic ozonation with $250 \mathrm{mg} \mathrm{L}^{-1}$ of $\mathrm{PdO} / \mathrm{CeO}_{2}$ when ozone in water had been completely consumed after $12 \mathrm{~min}$. Since oxalate concentration in adsorption alone reached equilibrium within $3 \mathrm{~min}$ at this $\mathrm{PdO} / \mathrm{CeO}_{2}$ dose, the further oxalate loss might be due to the degradation of adsorbed 


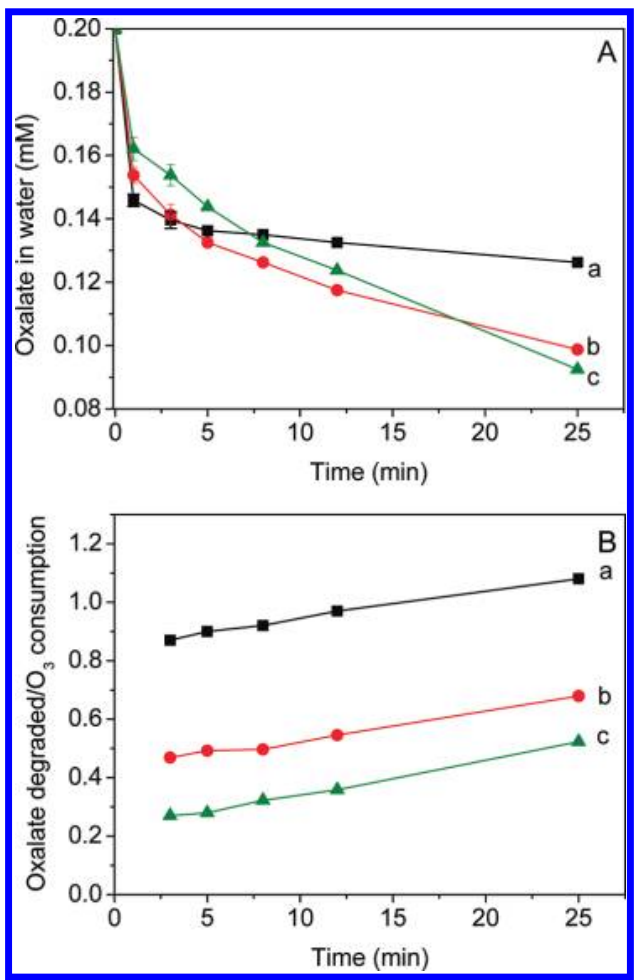

Figure 3. Effect of ozone dose (a- $0.05 \mathrm{mM}$, b- $0.13 \mathrm{mM}$, c- $0.18 \mathrm{mM}$ ) on oxalate removal (A) and the effective ozone consumption ratio (B) in the catalytic ozonation. Experimental conditions: initial oxalate concentration $=0.2 \mathrm{mM}$, catalyst dose $=150 \mathrm{mg} \mathrm{L}^{-1}, T=21{ }^{\circ} \mathrm{C}, 10 \mathrm{mM}$ tetraborate buffered $\mathrm{pH}=6.5$.

oxalate by adsorbed ozone or new oxidant species and a further adsorption.

The loss of oxalate during the catalytic ozonation with different catalyst doses compensated well for TOC loss (Figure S3, Supporting Information). It means that the oxalate was oxidized directly into $\mathrm{CO}_{2}$ with no formation of other stable organic intermediates, consistent with the results found in homogeneous catalytic ozonation of oxalate with $\mathrm{Co}^{2+} .{ }^{10}$

The effective ozone consumption ratio for oxalate degradation was calculated as the oxalate degradation (total removal subtracted by the removal in adsorption alone) per mole of ozone consumed. Figure $2 \mathrm{~B}$ shows that this ratio substantially increased from 0.05 to 0.5 in $25 \mathrm{~min}$ reaction as the catalyst dose increased from 0 to $250 \mathrm{mg} \mathrm{L}^{-1}$.

Effect of Ozone Dose. Over half of oxalate removal always occurred within the first $3 \mathrm{~min}$ of reaction in $\mathrm{O}_{3} /\left(\mathrm{PdO} / \mathrm{CeO}_{2}\right)$ (shown in Figure 1A and 2A). It was expected that the increase of ozone dose will improve oxalate removal in this initial reaction phase. However, the increase of ozone dose from 0.05 to $0.18 \mathrm{mM}$ reduced oxalate removal rate (Figure $3 \mathrm{~A}$ ). The positive effect of increasing ozone dose on oxalate degradation rate was observed only after the initial phase. Because aqueous ozone concentration was relatively high in the initial phase compared with the following phase (Figure S4, Supporting Information), the result suggests that molecular ozone might not be the oxidant species directly responsible for the oxalate degradation. It is likely that several oxygen species can be formed in sequence from ozone decomposition on the catalyst surface. Ozone might compete with oxalate to react with some of the new oxygen species that are effective for oxalate degradation, thus leading to

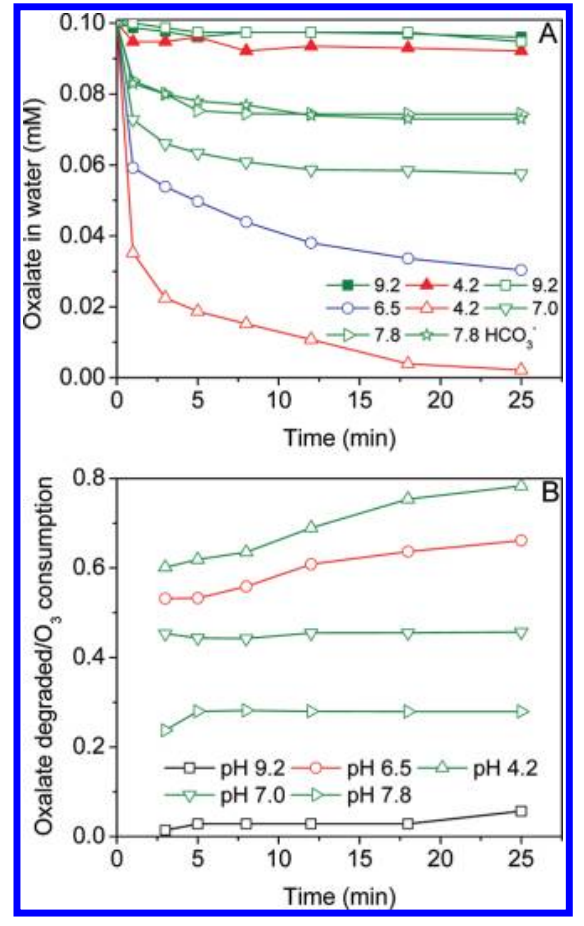

Figure 4. Effect of $\mathrm{pH}$ on oxalate removal in ozonation alone (solid symbols) and catalytic ozonation (open symbols) (A) and the effective ozone consumption ratio (B). Experimental conditions: ozone dose $=$ $0.09 \mathrm{mM}$, initial oxalate concentration $=0.1 \mathrm{mM}$, catalyst dose $=150 \mathrm{mg} \mathrm{L}^{-1}$, $T=21{ }^{\circ} \mathrm{C}, 10 \mathrm{mM}$ tetraborate buffer and diluted $\mathrm{HNO}_{3}$ adjusted $\mathrm{pH}$, $2.5 \mathrm{mM}$ bicarbonate was also used for $\mathrm{pH}$ 7.8.

the negative effect on oxalate degradation in the initial phase when ozone dose was raised.

At the dose of $0.05 \mathrm{mM}$, ozone in water was totally consumed in 5 min (Figure S4, Supporting Information). However, oxalate was further removed by $0.007 \mathrm{mM}$ thereafter, which is similar to that observed in Figure 2A. The effective ozone consumption ratio for oxalate degradation increased from 0.5 to around 1.0 as the ozone dose decreased from 0.18 to $0.05 \mathrm{mM}$ (Figure 3B). It may indicate that ozone reacts with some of the new oxidant species that are effective for oxalate degradation, thus reducing the effective ozone consumption ratio at high ozone doses.

Effect of $\mathrm{pH}$. Owing to ozone reactions with $\mathrm{OH}^{-}$and some dissociating organics, ozone decomposition in water and the hydroxyl radical generation can be significantly accelerated at elevated $\mathrm{pHs} .{ }^{8,16,17}$ Ozone decomposition at $\mathrm{pH} 9.2$ was so fast that there was nearly no difference in residual ozone between ozonation alone and catalytic ozonation (Figure S5, Supporting Information). The fast ozone decomposition at this $\mathrm{pH}$ definitely accelerated hydroxyl radical generation. However, only about 5\% of oxalate was removed during ozonation alone and catalytic ozonation (Figure 4A). The low efficiency of hydroxyl radical oxidation can be ascribed to its much higher reaction rate with molecular ozone $\left(1 \times 10^{8}-2 \times 10^{9} \mathrm{M}^{-1} \mathrm{~s}^{-1}\right)^{8}$ than oxalate oxidation $\left(7.7 \times 10^{6} \mathrm{M}^{-1} \mathrm{~s}^{-1}\right) .{ }^{10}$ The disappearance of catalytic effect at this $\mathrm{pH}$ can be ascribed to the fast ozone decomposition in water, which reduced significantly the chances of ozonecatalyst surface interaction.

As the $\mathrm{pH}$ was decreased, oxalate was removed by $25 \%, 40 \%$, $70 \%$, and $98 \%$ during catalytic ozonation at $\mathrm{pH} 7.8,7.0,6.5$, and 4.2, respectively (Figure 4A). In parallel, the ozone decomposition 
rate was also enhanced by the catalyst with that at $\mathrm{pH} 4.2$ was slightly higher than that at $\mathrm{pH} 6.5$ (Figure S5, Supporting Information). A similar observation was described during the catalytic ozonation of oxalate with $\mathrm{Co}^{2+} \cdot 10$ Oxalate adsorption was promoted by the decrease of $\mathrm{pH}$. About $2 \%, 9 \%$, and $28 \%$ oxalate was removed in adsorption alone at $\mathrm{pH} 7.8,6.5$ and 4.2, respectively (not shown). As the $\mathrm{pH}_{\mathrm{pzc}}$ of $\mathrm{PdO} / \mathrm{CeO}_{2}$ is 5.4 , it became more positively charged at lower $\mathrm{pH}$, improving oxalate adsorption through electrostatic attraction. Therefore, the improvement of oxalate removal at a lower $\mathrm{pH}$ is related to enhanced oxalate adsorption on the catalyst which might further promote surface oxalate degradation during catalytic ozonation.

The effective ozone consumption ratio in catalytic ozonation also increased from 0.06 to 0.78 as the $\mathrm{pH}$ decreased from 9.2 to 4.2 (Figure 4B). The low ratio at alkaline $\mathrm{pH}$ possibly is due to 1 ) fast ozone depletion in water which reduced the chances for ozone-catalyst interaction and 2) activity decrease of the catalyst caused by the negative effect of high $\mathrm{pH}$ on oxalate adsorption.

No Hydroxyl Radical Generation. The introduction of $\mathrm{t}-\mathrm{BuOH}$ into the reaction solution showed nearly no influence on ozone decomposition and oxalate degradation in the catalytic ozonation (Figure S6A and S6B, Supporting Information). It is clear that hydroxyl radical is not involved in the catalytic ozone decomposition and oxalate degradation. Atrazine $\left(k_{\mathrm{O} 3}=6 \mathrm{M}^{-1} \mathrm{~s}^{-1}\right.$, $\left.k_{\bullet \mathrm{OH}}=3 \times 10^{9} \mathrm{M}^{-1} \mathrm{~s}^{-1}\right)^{8}$ was used as an additional probe compound for the catalytic ozonation (Figure S7, Supporting Information). Degradation rates of atrazine at trace level during catalytic ozonation in the presence or the absence of oxalate were similar. Pines and Reckhow observed that hydroxyl radical was a byproduct of oxalate degradation in catalytic ozonation with cobalt ion. ${ }^{10}$ However, no hydroxyl radical was generated from the catalytic oxalate degradation here, indicating that the degradation pathways involved in the two processes are different. The atrazine degradation rate during catalytic ozonation was much lower than during ozonation alone, proving again that hydroxyl radical was not generated from the catalytic ozone decomposition.

Stable Activity. Oxalate stock solution was intermittently added into the reactor by 30 times in the semicontinuous catalytic ozonation to test the stability of the catalyst. The amount of oxalate added into the reaction solution at the end of each $10 \mathrm{~min}$ reaction can increase oxalate concentration by $0.2 \mathrm{mM}$. In most cases, nearly all of the oxalate added was degraded within the $10 \mathrm{~min}$ reaction (Figure S8, Supporting Information). No decrease of the oxalate removal was observed with the increase of reaction runs in the semicontinuous reaction. Therefore, the activity of $\mathrm{PdO} / \mathrm{CeO}_{2}$ remained relatively stable for our experimental conditions.

Active Sites, Oxidant Species, and Reaction Pathway. Figure 5A-C shows ATR-FTIR spectra obtained from PdO/ $\mathrm{CeO}_{2}, \mathrm{CeO}_{2}$, and $\mathrm{PdO}$ in water with and without the presence of ozone and oxalate, respectively. New double reflectance bands with weak intensities appeared for $\mathrm{PdO} / \mathrm{CeO}_{2}$ (2086 and $2048 \mathrm{~cm}^{-1}$ ) and $\mathrm{PdO}\left(2040\right.$ and $2014 \mathrm{~cm}^{-1}$ ) in contact with aqueous ozone. According to refs $18-20$, these bands can be assigned to distorted molecular ozone vibrations with interaction of ozone with surface metal sites. There was no adsorbed ozone features for $\mathrm{CeO}_{2}$ in contact with aqueous ozone. These results indicate that $\mathrm{PdO}$ is the component that adsorbs ozone. The reflectance of adsorbed ozone on the catalyst shifted to higher wavenumbers as compared with $\mathrm{PdO}$ alone, suggesting that the $\mathrm{CeO}_{2}$-supported $\mathrm{PdO}$ has a stronger binding or distortion effect

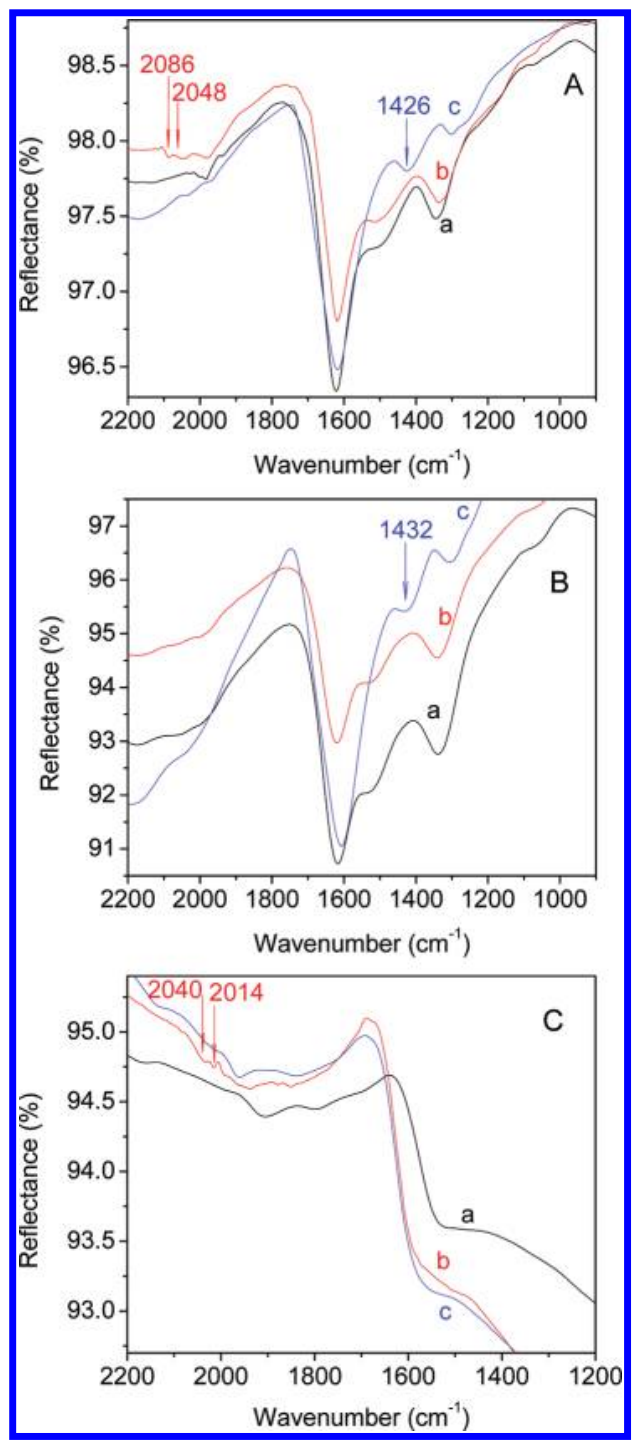

Figure 5. ATR-FTIR spectra of $\mathrm{PdO} / \mathrm{CeO}_{2}(\mathrm{~A}), \mathrm{CeO}_{2}$ (B), and $\mathrm{PdO}$ (C) in contact with water (curve a), aqueous ozone (curve b), and aqueous oxalate (curve c).

for adsorbed ozone molecule. A stronger distortion can make the adsorbed ozone more unstable against dissociation. ${ }^{18}$ Therefore, the faster ozone decomposition on the catalyst than that on $\mathrm{PdO}$ alone (shown in Figure 1B) can be related to the higher affinity of the catalyst for ozone molecule.

New reflectance bands at 1426 and $1432 \mathrm{~cm}^{-1}$ appeared for $\mathrm{PdO} / \mathrm{CeO}_{2}$ and $\mathrm{CeO}_{2}$ in contact with oxalate solution, respectively. Oxalate was reported to have two characteristic IR bands in the region of $1650-1550$ and $1400 \mathrm{~cm}^{-1} \cdot{ }^{21}$ However, oxalate in water only showed the apparent $1400 \mathrm{~cm}^{-1}$ peak with the ATR-FTIR (Figure S9, Supporting Information), probably because pure water that was used for a background scan also had a reflectance around $1600 \mathrm{~cm}^{-1}$. The $1400 \mathrm{~cm}^{-1}$ band which is due to $\mathrm{C}=\mathrm{O}$ stretch shifted to higher wavenumbers in the presence of $\mathrm{CeO}_{2}$ and $\mathrm{PdO} / \mathrm{CeO}_{2}$. According to Marley et al., ${ }^{21}$ this result indicates that oxalate was adsorbed onto cerium sites of the oxides forming surface complexes.

Although oxalate can be adsorbed on $\mathrm{CeO}_{2}$ through surface complexation, $\mathrm{CeO}_{2}$ alone had nearly no activity for oxalate 


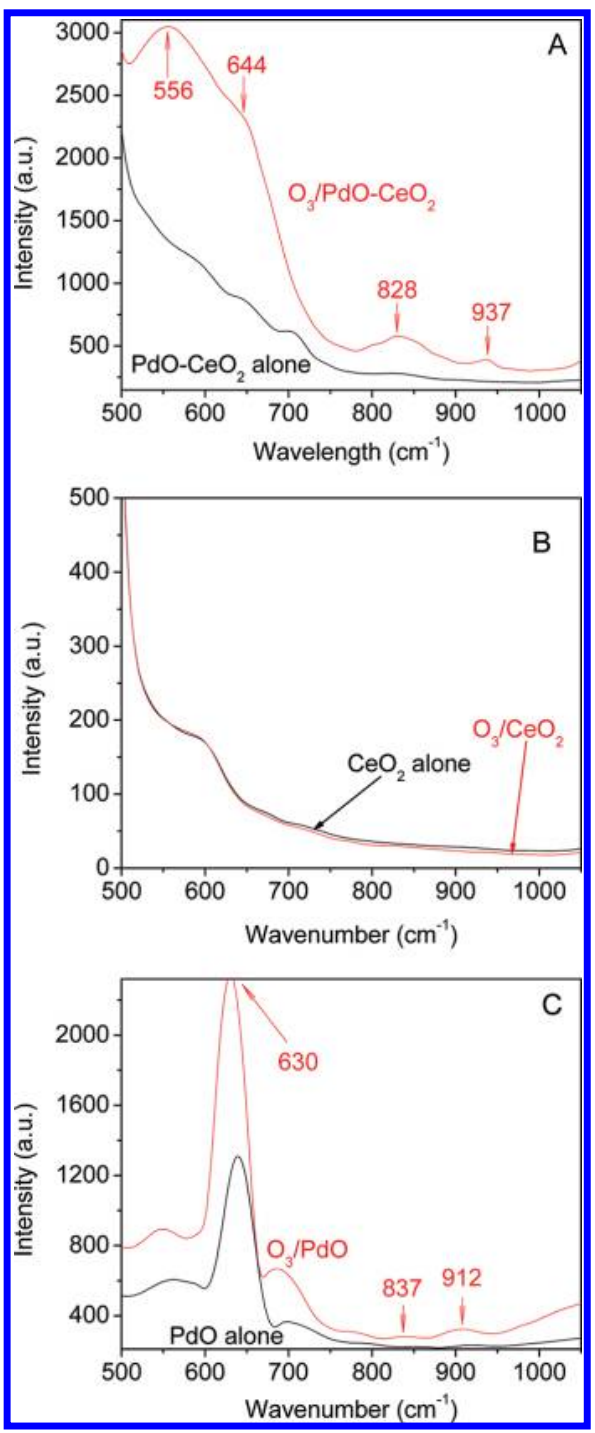

Figure 6. Raman spectra of $\mathrm{PdO} / \mathrm{CeO}_{2}(\mathrm{~A}), \mathrm{CeO}_{2}$ (B), and $\mathrm{PdO}(\mathrm{C})$ with and without the presence of ozone.

degradation during ozonation (shown in Figure 1A). Therefore, direct oxidation of the cerium-oxalate complex by molecular ozone is still not the catalytic ozonation pathway. It is likely that the adsorbed ozone molecule can produce more active surface oxygen species that are quite selective for the complex degradation.

In situ Raman spectroscopy had been used to characterize intermediate oxygen species formed on manganese oxides in contact with gaseous ozone. ${ }^{19,22}$ It was applied here to get insights on ozone decomposition on the catalyst. Figure 6A-C shows Raman spectra of $\mathrm{PdO} / \mathrm{CeO}_{2}, \mathrm{CeO}_{2}$, and $\mathrm{PdO}$ respectively with and without the presence of ozone. Ozone itself had no Raman signal in this spectrum range. The intensities of the peak at $556 \mathrm{~cm}^{-1}$ and the shoulder at $644 \mathrm{~cm}^{-1}$ increased significantly for $\mathrm{PdO} / \mathrm{CeO}_{2}$ in contact with ozone (Figure $6 \mathrm{~A}$ ). The $556 \mathrm{~cm}^{-1}$ feature arises from lattice oxygen vacancies in $\mathrm{CeO}_{2}{ }^{23,24}$ The $644 \mathrm{~cm}^{-1}$ is ascribed to new palladium oxide species. ${ }^{25,26} \mathrm{CeO}_{2}$ has a special property of changing oxidation state of lattice Ce between $\mathrm{Ce}^{\mathrm{III}}$ and $\mathrm{Ce}^{\mathrm{IV}}$ through oxygen release and storage. ${ }^{27}$ The intensity increase of the $556 \mathrm{~cm}^{-1}$ peak means that lattice $\mathrm{Ce}{ }^{\mathrm{III}}$ content in the $\mathrm{CeO}_{2}$ support increased.
The lattice $\mathrm{Ce}^{\mathrm{III}}$ content increase can stabilize surface metal ions when their oxidation states increase. ${ }^{28}$ It is likely that here the lattice oxygen vacancy formation in the $\mathrm{CeO}_{2}$ support is due to the stabilization of the surface palladium ions at the strongly oxidative atmosphere. Two new broad peaks appeared at 828 and $937 \mathrm{~cm}^{-1}$. They are characteristic features of surface peroxide $\left({ }^{*} \mathrm{O}_{2}\right)$ and surface atomic oxygen $\left({ }^{*} \mathrm{O}\right)$, respectively. ${ }^{19,22-24}$ When the ozone flow was cut off, the peaks slowly decreased (Figure S10, Supporting Information), indicating the catalyst can recover itself.

The Raman spectra of $\mathrm{CeO}_{2}$ with and without the presence of ozone were nearly the same (Figure 6B). No intensity increase at $556 \mathrm{~cm}^{-1}$ was observed in the presence of ozone, meaning that the oxygen vacancies cannot be formed when ozone contacts with $\mathrm{CeO}_{2}$ alone. The features of surface palladium oxide, surface peroxide, and atomic oxygen were all observed for $\mathrm{PdO}$ in contact with ozone (Figure 6C). However, the peak wavenumbers of surface PdO $\left(630 \mathrm{~cm}^{-1}\right)$ and atomic oxygen $\left(912 \mathrm{~cm}^{-1}\right)$ were lower than the values observed for $\mathrm{PdO} / \mathrm{CeO}_{2}$ and higher for peroxide $\left(837 \mathrm{~cm}^{-1}\right)$. This result indicates that there is a strong interaction between the $\mathrm{CeO}_{2}$ support and the palladium ion which led to the changes of binding strength between palladium and these surface oxygen-containing species.

Our results clearly showed that $\mathrm{PdO}$ on the catalyst surface is the active site in inducing the decomposition of ozone into the intermediate oxygen species. Since ozone can adsorb onto PdO (shown in Figure 5A and 5C), it is possible that the adsorbed ozone further decomposed to surface atomic oxygen and gaseous $\mathrm{O}_{2}$ (eq 1). Another ozone molecule would react with the surface atomic oxygen forming a surface peroxide species and a gaseous $\mathrm{O}_{2}$ (eq 2). Because the peak of the surface peroxide disappeared when ozone was removed, the surface peroxide would further decompose to gaseous $\mathrm{O}_{2}$ (eq 3). Such a catalytic ozone decomposition process under the mimic aqueous condition is consistent with gaseous ozone decomposition on manganese oxides $^{19,22}$

$$
\begin{aligned}
& P d^{*}+\mathrm{O}_{3} \rightarrow P d^{*} \mathrm{O}+\mathrm{O}_{2} \\
& P d^{*} \mathrm{O}+\mathrm{O}_{3} \rightarrow P d^{*} \mathrm{O}_{2}+\mathrm{O}_{2} \\
& P d^{*} \mathrm{O}_{2} \rightarrow P d^{*}+\mathrm{O}_{2}
\end{aligned}
$$

The Raman feature of surface atomic oxygen is attributed to the stretches of metal-oxygen double bond $\mathrm{Me}=\mathrm{O}^{29}$ The higher $\mathrm{Pd}=\mathrm{O}$ wavenumber observed on the $\mathrm{PdO} / \mathrm{CeO}_{2}$ indicates that the $\mathrm{CeO}_{2}$ support led to stronger affinity of palladium for the atomic oxygen. Such a kind of palladium-atomic oxygen interaction on the catalyst in comparison with that on PdO probably would increase the stability of the atomic oxygen and consequently reduce the rate of its reaction with ozone which forms surface peroxide. Because the oxidation potential of atomic oxygen (2.43 V in water) is much higher than that of peroxide $(1.35 \mathrm{~V}$ in protonated form $),{ }^{30}$ the surface atomic oxygen is likely the active oxygen species in the catalytic ozonation. The maximum effective ozone consumption ratio of the catalyst was observed to be around 1 for oxalate degradation under our experimental conditions (shown in Figure 3B). This result reinforces the hypothesis that the surface atomic oxygen is the major effective oxidant in the catalytic ozonation. If surface peroxide was effective for oxalate degradation, the maximum effective ozone consumption ratio would be around 0.5 ( 2 mols 
of $\mathrm{O}_{3}$ needed to produce surface peroxide). This point is also supported by the fact that high ozone concentration showed negative effect on oxalate degradation in the initial phase (shown in Figure 3A). Ozone in excess may react with surface atomic oxygen to produce surface peroxide. Our reaction mechanism hypothesis agrees with the fact that further oxalate degradation is observed after complete consumption of aqueous ozone (Figure 2A and 3A) because the adsorbed ozone on the catalyst decomposes to form atomic oxygen and it can survive for some time in absence of aqueous ozone (Figure S10, Supporting Information).

It has been reported that oxidative decarboxylation of $\mathrm{Ce}^{\mathrm{IV}}$ carboxylates occurs under heating conditions in water through one-electron transfer forming alkyl radical and two-electron transfer forming carbonium ion (eqs 4 and 5) 31,32 $^{3}$

$$
\begin{aligned}
& \mathrm{Ce}^{\mathrm{IV}}\left(\mathrm{O}_{2} \mathrm{CR}\right)_{3}{ }^{+} \rightarrow \mathrm{Ce}^{\mathrm{III}}\left(\mathrm{O}_{2} \mathrm{CR}\right)_{2}{ }^{+}+\mathrm{CO}_{2}+\mathrm{R}^{\bullet} \\
& \mathrm{R}^{\bullet}+\mathrm{Ce}^{\mathrm{IV}} \rightarrow \mathrm{Ce}^{\mathrm{III}}+\mathrm{R}^{+}
\end{aligned}
$$

In the surface cerium-oxalate complex, oxalate partially donates its electron density to $\mathrm{Ce}^{\mathrm{IV}}$. Because atomic oxygen has a higher oxidation potential than $\mathrm{Ce}^{\mathrm{IV}}(1.70 \mathrm{~V})$, it is likely that the surface atomic oxygen extracts one or two electrons from the surface cerium-oxalate complex, thus initiating oxidative decarboxylation under mild conditions without reducing surface $\mathrm{Ce}^{\mathrm{IV}}$. The high efficiency of the catalytic ozonation with $\mathrm{PdO} / \mathrm{CeO}_{2}$ in oxalate degradation can then be related to a synergetic effect between PdO and the support: 1) PdO acts as the active site to decompose ozone to surface atomic oxygen, and 2) the support $\mathrm{CeO}_{2}$ activates oxalate in reaction with the surface atomic oxygen through forming surface complexes. In addition, the $\mathrm{CeO}_{2}$ support also promotes the adhesion and decomposition of ozone on PdO. The strong affinity probably increased the stability of the surface atomic oxygen against the fast reaction with ozone forming peroxide.

This work shows potentially effective degradation for polar refractory organics with composite metal oxide-assisted ozonation. It would be also promising for the degradation of hydrophilic natural organic matter (NOM) with high carboxylic contents known as refractory to conventional water treatments and one of the precursors of disinfection byproduct. ${ }^{33}$ Future research in following aspects might be necessary for the preparation of active catalysts and the application: 1) the influence of coordination affinity for target compounds on its degradation efficiency when another metal oxide is combined with $\mathrm{CeO}_{2}$ as a hybrid support, 2) activity changes when other metal oxides that can decompose ozone are supported on $\mathrm{CeO}_{2}$ as ozone active sites, and 3) degradation of polar refractory compounds and hydrophilic NOM components that cannot be effectively removed in hydroxyl radical oxidation.

\section{ASSOCIATED CONTENT}

S Supporting Information. One table and ten figures. This material is available free of charge via the Internet at http://pubs. acs.org.

\section{AUTHOR INFORMATION}

\section{Corresponding Author}

*Phone: + 966 (0) 2808 2984. E-mail: jp.croue@kaust.edu.sa.

\section{ACKNOWLEDGMENT}

We want to thank Dr. Yang Yang and Mr. Qingxiao Wang of Imaging and Characterization Laboratory of KAUST for their help in performing Raman and STEM analysis and Dr. Cyril Aubry, Ms. Tong Zhan, and Dr. Min Yoon of WDRC of KAUST in TEM, ICP-MS, and IC analysis. We also want to thank our anonymous reviewers for their valuable comments to improve this work.

\section{REFERENCES}

(1) Nawrocki, J.; Kasprzyk-Horden, B. The efficiency and mechanisms of catalytic ozonation. Appl. Catal., B 2010, 99, 27-42.

(2) Zhang, T.; Li, C.; Ma, J.; Tian, H.; Qiang, Z. Surface hydroxyl groups of synthetic a-FeOOH in promoting $\bullet \mathrm{OH}$ generation from aqueous ozone: Property and activity relationship. Appl. Catal. B 2008, 82, 131-137.

(3) Yang, L.; Hu, C.; Nie, Y.; Qu, J. Catalytic ozonation of selected pharmaceuticals over mesoporous alumina-supported manganese oxide. Environ. Sci. Technol. 2009, 43, 2525-2529.

(4) Zhao, L.; Sun, Z.; Ma, J. Novel relationship between hydroxyl radical initiation and surface group of ceramic honeycomb supported metals for the catalytic ozonation of nitrobenzene in aqueous solution. Environ. Sci. Technol. 2009, 43, 4157-4163.

(5) Andreozzi, R.; Insola, A.; Caprio, V.; Marotta, R.; Tufano, V. The use of manganese dioxide as a heterogeneous catalyst for oxalic acid ozonation in aqueous solution. Appl. Catal., A 1996, 138, 75-81.

(6) Delanoe, F.; Acedo, B.; Vel Leitner, N. K.; Legube, B. Relationship between the structure of $\mathrm{Ru} / \mathrm{CeO}_{2}$ catalysts and their activity in the catalytic ozonation of succinic acid aqueous solutions. Appl. Catal. B 2001, 29, 315-325.

(7) Beltran, F. J.; Rivas, F. J.; Montero-de-Espinosa, R. Iron type catalysts for the ozonation of oxalic acid in water. Water Res. 2005, $39,3553-3564$.

(8) von Gunten, U. Ozonation of drinking water: part I.Oxidation kinetics and product formation. Water Res. 2003, 37, 1443-1467.

(9) Hammes, F.; Salhi, E.; Koster, O.; Kaiser, H. P.; Egli, T.; von Gunten, U. Mechanistic and kinetic evaluation of organic disinfection by-product and assimilable organic carbon (AOC) formation during the ozonation of drinking water. Water Res. 2006, 40, 2275-2286.

(10) Pines, D. S.; Reckhow, D. A. Effect of dissolved cobalt(II) on the ozonation of oxalic acid. Environ. Sci. Technol. 2002, 36, 4046-4051.

(11) Beltran, F. J.; Rivas, F. J.; Montero-de-Espinosa, R. Ozoneenhanced oxidation of oxalic acid in water with cobalt catalysts. 2 . Heterogeneous catalytic ozonation. Ind. Eng. Chem. Res. 2003, 42, 3218 3224.

(12) Avramescu, S. M.; Bradu, C.; Udrea, I.; Mihalache, N.; Ruta, F. Degradation of oxalic acid from aqueous solutions by ozonation in presence of $\mathrm{Ni} / \mathrm{Al}_{2} \mathrm{O}_{3}$ catalysts. Catal. Commun. 2008, 9, 2386-2391.

(13) Jen, H. W.; Graham, G. W.; Chun, W.; McCabe, R. W.; Cuif, J. P.; Deutsch, S. E.; Touret, O. Characterization of model automotive exhaust catalysts: Pd on ceria and ceria-zirconia supports. Catal. Todav 1999, 50, 309-328.

(14) Lin, J.; Kawai, A.; Nakajima, T. Effective catalysts for decomposition of aqueous ozone. Appl. Catal. B 2002, 39, 157-165.

(15) Zhang, T.; Chen, W.; Ma, J.; Qiang, Z. Minimizing bromate formation with cerium dioxide during ozonation of bromide-containing water. Water Res. 2008, 42, 3651-3658.

(16) Hoigné, J.; Bader, H. Rate constants of reactions of ozone with organic and inorganic compounds in water. II. Dissociating organic compounds. Water Res. 1983, 17, 185-94.

(17) Xiong, F.; Croué, J. P.; Legube, B. Long-term ozone consumption by aquatic fulvic acids acting as precursors of radical chain reactions. Environ. Sci. Technol. 1992, 26, 1059-1064.

(18) Bulanin, K. M.; Lavalley, J. C.; Tsyganenko, A. A. IR spectra of adsorbed ozone. Colloids Surf. A 1995, 101, 153-158. 
(19) Radhakrishman, R.; Oyama, S. T. Ozone decomposition over manganese oxide supported on $\mathrm{ZrO}_{2}$ and $\mathrm{TiO}_{2}$ : A kinetic study using in situ laser Raman spectroscopy. L. Catal. 2001, 199, 282-290.

(20) Zeng, Y.; Liu, Z.; Qin, Z.; Liu, H. Infrared study on adsorption of $\mathrm{O}_{3}$ at $\mathrm{SnO}_{2}$ surface. Spectr. Spectral Anal. 2008, 28, 1035-1038.

(21) Marley, N. A.; Bennett, P.; Janecky, D. R.; Gaffney, J. S. Spectroscopic evidence for organic diacid complexation with dissolved silica in aqueous systems I. Oxalic acid. Org. Geochem. 1989, 14, $525-528$.

(22) Li, W.; Gibbs, G. V.; Ted Oyama, S. Mechanism of ozone decomposition on a manganese oxide catalyst. 1. In situ Raman spectroscopy and $\mathrm{Ab}$ initio molecular orbital calculations. I. Am. Chem. Soc. 1998, 120, 9041-9046.

(23) Wu, Z.; Li, M.; Howe, J.; Meyer, H. M.; Overbury, S. H. Probing defect sites on $\mathrm{CeO}_{2}$ nanocrystals with well-defined surface planes by Raman spectroscopy and $\mathrm{O}_{2}$ adsorption. Langmuir 2010, 26, 1659516606.

(24) Vindigni, F.; Manzoli, M.; Damin, A.; Tabakova, T.; Zecchina, A. Surface and inner defects in $\mathrm{Au} / \mathrm{CeO} 2$ WGS catalysts: Relation between Raman properties, reactivity and morphology. Chem.-Eur. I. 2011, 17, 4356-4361.

(25) Otto, K.; Hubbard, C. P.; Weber, W. H.; Graham, G. W. Raman spectroscopy of palladium oxide on r-alumina applicable to automotive catalysts. Appl. Catal., B 1992, 1, 317-327.

(26) Demoulin, O.; Navez, M.; Gaigneaux, E. M.; Ruiz, P.; Mamede, A. S.; Grangerb, P.; Payen, E. Operando resonance Raman spectroscopic characterization of the oxidation state of palladium in $\mathrm{Pd} / \mathrm{g}-\mathrm{Al}_{2} \mathrm{O}_{3}$ catalysts during the combustion of methane. Phys. Chem. Chem. Phys. 2003, 5, 4394-4401.

(27) Yao, H. C.; Yu Yao, Y. F. Ceria in automotive exhaust catalysis I. Oxygen storage. I. Catal. 1984, 86, 254-265.

(28) Mayernick, A. D.; Janik, M. J. Methane oxidation on Pd-Ceria: A DFT study of the mechanism over $\mathrm{Pd}_{\mathrm{x}} \mathrm{Ce}_{1-\mathrm{x}} \mathrm{O}_{2}, \mathrm{Pd}$, and PdO. I. Catal. 2011, 278, 16-25.

(29) Che, M.; Tench, A. J. Characterization and reactivity of mononuclear oxygen species on oxide surfaces. Adv. Catal. 1982, 31, 78-128.

(30) Bharara, M. S.; Atwood, D. A. Oxygen: Inorganic Chemistry. Encyclopedia of Inorganic Chemistry; John Wiley \& Sons: New York, 2006.

(31) Sheldon, R. A.; Kochi, J. K. Photochemical and thermal reduction of cerium (IV) carboxylates: Formation and oxidation of alkyl radicals. I. Am. Chem. Soc. 1968, 90, 6688-6698.

(32) Serguchev, Y. A.; Beletskaya, I. P. Oxidative decarboxylation of carboxylic acids. Russ. Chem. Rev. 1980, 49, 1119-1134.

(33) Dickenson, E. R. V.; Summers, R. S.; Croué, J. P.; Gallard, H. Haloacetic acid and trihalomethane formation from the chlorination and bromination of aliphatic $\beta$-dicarbonyl acid model compounds. Environ. Sci. Technol. 2008, 42, 3226-3233. 